\title{
The Influence of Personality on Job Satisfaction At PT. Surya Windu Pertiwi Serdang Bedagai
}

\author{
Nanda Putra ${ }^{1}$, Risa Kartika Lubis ${ }^{2}$
}

${ }^{1}$ Program Studi Manajemen, Sekolah Tinggi Ilmu Ekonomi LMII, Jalan Kolam Nomor 39 Medan Estate, Sumatera Utara, 20371, Indonesia ${ }^{2}$ STMIK Pelita Nusantara, Jl. Iskandar Muda No.1 Medan.

Email: ${ }^{1}$ nandaputra789@gmail.com; ${ }^{2}$ risakartika@gmail.com

\section{A R T I C L E I N F O \\ Article history: \\ Received: $22-10-2020$ \\ Revised: 01-03-2020 \\ Accepted: 01-04-2021}

Keywords:

personality;

Job Statisfaction;

Influence of Personality.

\author{
A B S T R A C T
}

This study aims to analyze personality, job satisfaction and the influence of personality on job satisfaction of employees of PT Surya Windu Pertiwi Serdang Bedagai. Respondents in this study were employees of PT Surya Windu Pertiwi Serdang Bedagai consisting of 43 respondents. The data analysis method used is descriptive statistics and simple regression. The results of the test show that the personality of openees to experience is a prominent personality of the employees of PT Surya Windu Pertiwi Serdang Bedagai with an average score of 3.8889. Meanwhile, the average value of descriptive statistics for the job satisfaction variable was 3.1457, indicating that the employees of PT Surya Windu Pertiwi Serdang Bedagai still did not have good job satisfaction. The results of the analysis show that personality does not have a positive and significant effect on job satisfaction of employees with a P-value of 0.382 greater than 0.05 . The managerial implication that can be given is that companies need to consider the factors of employee personality, especially when recruiting employees. Companies also need to consider aspects of job satisfaction, especially in terms of good salaries

Copyright (C) 2021 Journal of Management Science (JMAS). All rights reserved,

\section{Introduction}

Employees are the main asset of the company because they play an important role in carrying out the business activities of the organization or company. Employees in a company are a collection of various individuals who have different characteristics where these differences will certainly be able to make each individual have differences in their assessment of various things, for example differences in job satisfaction perceptions (Staw \& Cohen, 2015).

According to (Gibson et al, 2016) the definition of personality is a set of characteristics and tendencies that are stable and determine general characteristics and differences in a person's behavior. (Kreitner \& Kinicki, 2017) suggest that personality is a combination of stable physical and mental characteristics that give an individual identity. Meanwhile (Robbins, 2018) states that personality is the total amount of the way an individual acts and interacts with others. Based on this understanding, it can be concluded that personality includes all types of behavior and traits that are typical and predictable in a person, which are used to react and adapt to stimuli, so that the behavior pattern is a unique functional unit for that individual.

Job satisfaction is an important topic in organizational research because it has an influence on the overall well-being of the organization, for example, satisfied employees will create a more positive work environment for the organization (Patrick, 2018).

There are several types of personalities that are considered suitable for work at PT Surya Windu Pertiwi, namely Openess to experience, where as the largest shrimp breeding company in North Sumatra this personality is considered appropriate because it will relate to the community or other people in general. The conscientiousness personality is also considered suitable for work in shrimp nurseries because the demands for achieving very high yields in shrimp breeding such as producing high quality shrimp. With increasingly tight competition, especially in shrimp breeding companies, it is of course important for shrimp breeding companies such as PT Surya Windu Pertiwi to have employees who are highly committed to the company so that the company's nets will not be disturbed and good employees will certainly be able to provide a competitive advantage over competitors in breeding companies. others in Indonesia. From the above analysis, the researcher wanted to know how the influence of personality on employee job satisfaction at PT Surya Windu Pertiwi Serdang Bedagai 


\section{Method}

This study aims to see how the influence of personality on job satisfaction of employees of PT Surya Windu Pertiwi. The data instrument test conducted in this study was the validity and reliability test. The steps used in this research are descriptive statistics by looking at the average value of the respondents' answers. The population in this study were all employees of PT Surya Windu Pertiwi consisting of 45 employees. All employees of PT Surya Windu Pertiwi will be used as respondents for this study because the population is not too large. In taking the sample the researcher will conduct a census research, namely the entire population will be the respondents in this study because the observed population is not too large.

\section{Results and analysis}

\subsection{Data Validity Test}

An instrument is said to be valid if it is able to measure what is desired or to reveal data from the variables being studied appropriately. Validity testing is done by looking for the correlation of each indicator to its total score using the correlation technique formula "Product Moment". The basis for making the validity test decision is to compare the p-value with the level of significance as follows (Yarnest, 2016):

If the $\mathrm{p}$-value $<\alpha 0.05$, then the statement item is valid If $\mathrm{p}$ - value $>\alpha 0.05$ then the statement item is invalid

Table 1

personal variables validity test

\begin{tabular}{lcl}
\hline \multicolumn{1}{c}{ Indikator } & P-Value & Keputusan \\
\hline I see myself as someone who loves to talk & 0,000 & Valid \\
I see myself as a tough person & 0,004 & Valid \\
I see myself as an active person & 0,000 & Valid \\
I see myself as someone who has sympathy & 0,000 & Valid \\
I see myself as a kind person & 0,000 & Valid \\
I see myself as someone who has respect & 0,000 & Valid \\
I feel myself as someone who is organized & 0,000 & Valid \\
I feel that I am someone who is organized & 0,000 & Valid \\
I feel that I am someone who is detailed & 0,000 & Valid \\
I feel that I am a tense person & 0,002 & Valid \\
I feel that I am an anxious person & 0,003 & Valid \\
I feel that myself is a nervous person & 0,018 & Valid \\
I feel that I am someone who has broad interests & 0,000 & Valid \\
I feel that I am someone who has a high imagination. & 0,006 & Valid \\
I feel that I am a smart person & 0,001 & Valid \\
\hline Primary data sources were processed in 2020 & &
\end{tabular}

Primary data sources were processed in 2020

From the table of validity testing for the Personality variable, it is known that the p-value for all indicators is below 0.05 , which means that all internal indicators used in this study can form the personality variables used in this study.

Table 2

Validity Test Of Job Satisfaction

\begin{tabular}{lcc}
\hline \multicolumn{1}{c}{ Indikator } & P-Value & Keputusan \\
\hline I am satisfied with the work that I do & 0,000 & Valid \\
I am satisfied with the salary I receive every month & 0,000 & Valid \\
I am satisfied with the promotional opportunities that exist in this company & 0,000 & Valid \\
I am satisfied with my supervisor at work & 0,000 & Valid \\
I enjoy working together with my colleagues. & 0,000 & Valid \\
\hline Primary data sources were processed in 2020 & &
\end{tabular}

From the validity test table for the job satisfaction variable, it is known that the p-value for all indicators is below 0.05 , which means that all internal indicators used in this study can form the job satisfaction variables used in this study.

Data Reliability Test 
In this study, it was tested using the Inter-item Consistency. An instrument is considered reliable if it has an alpha $(\alpha)$ coefficient of 0.6 or more. The basis for decision making according to (Malhotra, 2017) reliable instruments are:

a. If Cronbach's coefficient alpha $(\alpha)$ testing $>0.6$ then the questions in the questionnaire are reliable.

b. If Cronbach's coefficient alpha $(\alpha)$ testing $\leq 0.6$ then the questions in the questionnaire are not suitable for use (not reliable).

Table 3

Reability Testing

\begin{tabular}{|c|c|c|}
\hline Variable & Cronbach Alpha & Decision \\
\hline Personality & 0,796 & Reliable \\
\hline Job satisfaction & 0,658 & Reliable \\
\hline
\end{tabular}

In the table above, the Cronbach's Alpha coefficient for each variable meets the reliability criteria recommended by now (greater than 0.60 ). Thus, the respondents' answers to the statements used to measure each of these constructs are consistent and the constructs can be trusted (reliable).

\subsection{Analysis of Research Results}

\section{a. Personality}

Table 4

Descriptive Statistics Of Personal Extraversion

\begin{tabular}{lc}
\multicolumn{2}{c}{ Descriptive Statistics Of Personal Extraversion } \\
\hline Indicator & Mean \\
\hline I see myself as someone who loves to talk & 3,6 \\
I see myself as a tough person & 3,4222 \\
I see myself as an active person & 3,8444 \\
$\quad$ Mean & $\mathbf{3 , 6 2 2}$ \\
\hline Primary data sources were processed in 2020
\end{tabular}

Judging from table 4 above shows the average value for extraversion personality is 3,622. The highest average score for extraversion personality is 3,8444 which indicates that PT Surya Windu Pertiwi employees are individuals who like to move or travel and have high initiative. The average value for other extraversion indicators, namely 3,6 and 3,422, shows that PT Surya Windu Pertiwi employees are individuals who like to communicate with others and also have an attitude that has a firm stand on something..

Table 5

Descriptive Statistics Of Agreeableness Personality

\begin{tabular}{ll}
\hline Indicator & Mean \\
\hline I see myself as someone who has sympathy & 3,9556 \\
I see myself as a kind person & 3,7556 \\
I see myself as someone who has respect & 3,9333 \\
Mean & $\mathbf{3 , 8 8 1 5}$ \\
\hline
\end{tabular}

If seen from table 5 above, it shows that the average score for agreeableness personality is 3.8815 . The highest average score for agreeableness personality is 3.9556 which indicates that the employees of PT Surya Windu Pertiwi are individuals who have good sympathy and can feel and consider other people's feelings. The average value for other indicators of agreeableness, which is 3.9333 , shows that the employees of PT Surya Windu Pertiwi are individuals who are able to respect other people and the average value of 3.7556 shows that the employees of PT Surya Windu Pertiwi are warm and loving individuals. help others.

Table 6

Descriptive Statistics Of Conscientiousness Personality

\begin{tabular}{ll}
\hline Indicator & Mean \\
\hline I feel myself as someone who is organized & 3,511 \\
I feel that I am someone who is organized & 3,5556 \\
I feel that I am someone who is detailed & 3,4889 \\
Mean & $\mathbf{3 , 5 1 8 5}$ \\
\hline
\end{tabular}

Primary data sources were processed in 2020 
If seen from table 6 above, it shows that the average value for conscientiousness personality is 3.5185 . The highest average score for conscientiousness personality is 3.5556, which indicates that PT Surya Windu Pertiwi employees are individuals who do something following the exact steps. The average value for other conscientiousness indicators is 3.511, indicating that the employees of PT Surya Windu Pertiwi are individuals who do everything neatly and well, the average value of 3.4889 shows that the employees of PT Surya Windu Pertiwi are still individuals. not careful in doing something.

Table 7

Descriptive Statistics Of Neuroticism Personality

\begin{tabular}{lc}
\hline \multicolumn{1}{c}{ Indikator } & Mean \\
\hline I feel that I am a tense person & 2,7556 \\
I feel that I am an anxious person & 2,6667 \\
I feel that myself is a nervous person & 2,5333 \\
\multicolumn{1}{c}{ Mean } & $\mathbf{2 , 6 5 1 9}$ \\
\hline
\end{tabular}

Primary data sources were processed in 2020

If seen from table 7 above, it shows that the average value for neuroticism personality is 2.6519 . The highest average score for neuroticism personality is 2.7556 , which indicates that the employees of PT Surya Windu Pertiwi are relaxed or not easily tense when facing a problem. The average value for other neuroticism indicators is 2,667, indicating that PT Surya Windu Pertiwi employees are individuals who have good self-confidence when facing pressure or problems and an average value of 2.5333 shows that PT Surya Windu Pertiwi employees are individuals. who is always calm when facing serious problems or problems.

Table 8

Descriptive Statistics Of Personality, Openess To Experience

\begin{tabular}{ll}
\hline Indicator & Mean \\
\hline I feel that I am someone who has broad interests & 3,9556 \\
I feel that I am someone who has a high imagination. & 3,8444 \\
I feel that I am a smart person & 3,8667 \\
Mean & $\mathbf{3 , 8 8 8 9}$ \\
\hline \multicolumn{2}{c}{ Primary data sources were processed in 2020 }
\end{tabular}

Based on table 8 above, it shows that the average value for the Openess to Experience personality is 3.889. The highest average score for Openess to Experience personality is 3.9556 which indicates that PT Surya Windu Pertiwi employees are individuals who have interests that are not only in one field or one type but in many things. The average value for other Openess to Experience indicators is 3,844 indicating that PT Surya Windu Pertiwi employees are individuals who are happy to imagine or describe something and the average value is 3.8667 , indicating that PT Surya Windu Pertiwi employees are individuals who have intellectuality. the good one.

Table 9

Descriptive Statistics of Overall Personality

\begin{tabular}{|c|c|}
\hline Description & Mean \\
\hline Extraversion & 3,622 \\
\hline Agreeableness & 3,8815 \\
\hline Conscientiousness & 3,5185 \\
\hline Neuroticism & 2,6519 \\
\hline Openess to Experience & 3,8889 \\
\hline
\end{tabular}

Based on table 9 above, it can be seen that the highest average value for personality variables is openness to experience, which is 3.8889, which means that employees are employees of PT Surya Windu Pertiwi who are individuals who have interests that are not only in one area or field. one kind only but in many things, happy to imagine something and have a good intellect. The high average value for the personal agreeableness variable is 3.8815, which means that the employees of PT Surya Windu Pertiwi are employees who can feel and consider the feelings of others, are able to respect others and value are individuals who are warm and like helping others.

The average value for extraversion personality is 3,622, indicating that the employees of PT Surya Windu Pertiwi are individuals who like to move or travel and have the initiative to be happy to communicate with others and also have an attitude that has a firm stand on something. And consicentiouness personality with an average of 3.5185 shows that a person who does something follows the exact steps, is an individual who does everything in a neat and good order and is an individual who is not careful in doing 
something. Meanwhile, the lowest average value of 2.6519 for the personality variable is neuroticism which shows the employees of PT Surya Windu Pertiwi are relaxed individuals or not easily tense when facing a problem, have good self-confidence when facing pressure or problems and are individuals. who is always calm when facing serious problems or problems.

\section{b. Job satisfaction}

Table 10

Descriptive Statistics Of Work Satisfaction Variables

\begin{tabular}{|c|c|}
\hline Indicator & Mean \\
\hline I am satisfied with the work that I do & 3,6 \\
\hline I am satisfied with the salary I receive every month & 2,2667 \\
\hline I am satisfied with the promotional opportunities that exist in this company & 3,0667 \\
\hline I am satisfied with my supervisor at work & 3,0444 \\
\hline I enjoy working together with my colleagues. & 3,7556 \\
\hline Mean & 3,1467 \\
\hline
\end{tabular}

Source: Data processed in 2020

Based on the results of descriptive statistics in table 10 above, it can be seen that the mean value for the job satisfaction variable is 3.1467 where these results indicate that the employees are quite satisfied working at PT Surya Windu Pertiwi. From the highest average value for the job satisfaction indicator of 3.7556 which shows the factor of a good co-worker who can be invited to work together so as to create a conducive work atmosphere is the main factor of job satisfaction that stands out for the employees of PT Surya Windu Pertiwi. The mean value of 3.6 indicates that the type of work done is the type of work that can shape the job satisfaction of employees. The mean value of 3.0444-3.0667 shows that employees are less satisfied with the supervisor and also with the opportunities for promotion given by the company, which means that employees are still not satisfied with how the boss leads and manages employees and feels that the opportunity for the promotion given by the company is still considered lacking. . The mean value of 2.2667 indicates that the salaries of the company are still considered unsatisfactory by employees.

3.3. Discussion

From the descriptive results for personality variables, it can be seen that the highest average value for personality variables is openness to experience, which is 3.8889 , which means that employees are employees of PT Surya Windu Pertiwi who have broad interests, high imagination and are intelligent. Personality with characteristics like this according to (Costa \& McRae, 2015) is included in the personality category of openness to experience, where the openness to experience personality is a characteristic with characteristics such as having an active imagination, having a high aesthetic taste and having a high curiosity. This personality is in accordance with the production department which is the object of this research because employees must strive to create something interesting and new that is different from competitors and because these characteristics will make the individual always look for everything new that does not exist or is not yet common which will be realized later. in the idea of producing a television show.

From the descriptive statistics of job satisfaction, it can be seen that the employees of PT Surya Windu Pertiwi already have job satisfaction even though their size is not high. Job satisfaction according to (Robbins, 2018) suggests that an individual's general attitude towards his job can be influenced by the job itself, wages, opportunities or promotions, supervision, and co-workers. The results of the descriptive statistics with the highest mean value indicate that the co-worker factor is the main factor affecting the job satisfaction of the employees of PT Surya Windu Pertiwi.

The results of testing the influence of personality on job satisfaction show that there is no influence of personality on job satisfaction and the results of this study are not in accordance with the results of previous research conducted by (Judge et al, 2017) which shows that there is an influence of personality on job satisfaction from employees. Therefore it can be said that the job satisfaction of the employees at PT Surya Windu Pertiwi cannot be determined by the personal characteristics of the employees of PT Surya Windu Pertiwi. In this case personal characteristics do not affect job satisfaction because in this company there is more interaction in the field than in the office so that the level of personality does not become a measure of job satisfaction and in the corporate environment also the majority of education only has high school degrees so that the level of personality has no effect on job satisfaction because in theory the higher a person's education, the more critical his idealistic level and personality.

\section{Conclusion}


Employees at PT Surya Windu Pertiwi generally show more personality openness to experience compared to other personality dimensions and this can be seen from the average value for the dimension of openness to experience which is the highest of 3.8889, which means the employee is an employee of PT Surya Windu. Pertiwi has broad interests, high imagination and is also intelligent.

The employees of PT Surya Windu Pertiwi have a level of job satisfaction as indicated by the average value for the job satisfaction variable of 3.1457. These results indicate that employees are quite satisfied with the work they do at PT Surya Windu Pertiwi.

The results of testing the effect of personality on job satisfaction show that there is no influence of personality on job satisfaction with a P-value of $0.382>0.05$, which means that the research hypothesis is rejected..

\section{Reference}

[1] Ahmadi, S.A.A.,Ahmadi.,F.,Zohrabi, Mina (2012)., The effect of the leadership style on the organizational commitment given the staff personality traits. Interdisclipinary Journal of Contemporary research in business Vol 4,No1 May.

[2] Allen, N.J. and Meyer, J.P. (2015), "The measure and antecedents of affective, continuance, and normative commitment to the organisation", Journal of Occupational Psychology, Vol. 63, pp. 1-18.

[3] Asep,Hermawan.,(2018) Metode Penelitian Bisnis, Penerbit FE Universitas Trisakti.

[4] Bruk-Lee, V., Khoury, H.A., Nixon, A.E., Goh, A. and Spector, P.E. (2019), "Replicating and extending past personality/job satisfaction meta-analyses", Human Performance, Vol. 22, pp. 156-89.

[5] Chandel, J.K., Sharma, S.K., \& Bansal, S.P (2016).Linking the big five personality domains to organizationalcommitment, International Journal of Research in Commerce, IT and Management, 1(3), pp. 19-24.

[6] Cooper, A. H., \& Viswesvaran, C. (2015). The Construct of work commitment: Testing an integative framework. . Psychological Bulletin, 241-259.

[7] Costa, J. P., \& Mc Crae, R. R. (2017). Looking Backward :Changes in the mean levels of persinality traits from 80 to 12 in D. In Cervone, \& Mischel, Advances in personality Science (pp. 219-237). New York: Guildford Press.

[8] Gibson, J. J., \& James H, J. D. (2016). Organization Behavior structure procesess. Chicago: IL Irwin.

[9] Jerningan , I. B., \& Kohut, G. F. (2017). Dimension of work Statisfaction as predictors of commitment type. Journal of Managerial Psychology, vol 7 pp 64-79.

[10] Kreitner, R, \& Kinicki, A. (2017). Oragnisational Behavior. England: MCGraw Hill.

[11] Malhotra, N. (2017). Marketing Research an Applied Orientation. New Jersey: Prentice Hall.

[12] Robbins, S. P. (2018). Essential of organisational Behavior. Newyork: McGraw Hill.

[13] Staw, B.M., \& Ross, J. (2015). Stability in the midst of change: A dispositional approach to job attitudes. Journal of Applied Psycholo y, 70, 469-480.

[14] Sekaran, U \& Bougie, R. (2018). Research methods for business: A skill building approach. 5th Edition. UK: John Willey \& Sons, Ltd

[15] Yarnest. 2014. Panduan Aplikasi Statistik. Dioma. Malang. 